\title{
The Silurian mesophotic coral ecosystems: 430 million years of photosymbiosis
}

\author{
Mikołaj K. Zapalski ${ }^{1}$ (D) Błażej Berkowski² ${ }^{2}$
}

Received: 6 September 2018/Accepted: 20 December 2018/Published online: 26 December 2018

(C) The Author(s) 2018

\begin{abstract}
The Silurian Period witnessed one of the most profound intervals of reef development in the history of the Earth, formed in large part by tabulate and rugose corals and stromatoporoid assemblages. One of the best-known examples of Silurian reefs (bioherms) is those exposed on the Baltic island of Gotland (Sweden). The stratigraphic sequence below these bioherms is represented by the Visby Beds (Lower Wenlock, ca. $430 \mathrm{Ma}$ ) that record in their lower sections (Lower Visby Beds) environments near the lower limit of the euphotic zone. Here, we describe platy tabulate coral assemblages from the uppermost Lower Visby Beds that represent a mesophotic coral ecosystem (MCE) potentially spread over $40 \mathrm{~km}$. This MCE is dominated by platy tabulate corals, with accessory branching tabulates and solitary and phaceloid rugose corals. Algae are absent, likely as a result of taphonomic bias. It is possible that other MCEs of similar age are recorded on other Silurian tropical shelves: Anticosti Island (Laurentia, present Arctic Canada) and Hiiumaa (Baltica, present Estonia), in particular, may possess candidate early Silurian MCE assemblages. At a minimum, however, tabulate corals acquired photosymbionts during the early Silurian (Wenlock), which resulted in the development of both MCEs and shallow-water reef systems and contributed to the great expansion of the mid-Palaeozoic reef complexes.
\end{abstract}

Topic Editor Morgan S. Pratchett

Mikołaj K. Zapalski

m.zapalski@uw.edu.pl

1 Faculty of Geology, University of Warsaw, Żwirki i Wigury 93, 02-089 Warsaw, Poland

2 Institute of Geology, Adam Mickiewicz University, B. Krygowskiego 12, 61-680 Poznan, Poland
Keywords Mesophotic coral ecosystems .

Photosymbiosis $\cdot$ Reef $\cdot$ Tabulate corals $\cdot$ Silurian

\section{Introduction}

Mesophotic coral ecosystems (MCEs) are communities dominated by zooxanthellate scleractinian corals that develop between 30 and $150 \mathrm{~m}$ depth (Lesser et al. 2009; Kahng et al. 2010). In general, it appears these ecosystems are more widespread geographically than their shallowwater counterparts (Bare et al. 2010). One of the most distinctive features of MCEs is the dominance of zooxanthellate corals that form platy colonies (Baker et al. 2016). Platy growth is broadly considered to be a photoadaptive morphological attribute (e.g. Graus and Macintyre 1976; Anthony and Hoegh-Guldberg 2003; Kahng et al. 2012, 2014) and generally does not occur in azooxanthellate species (Fricke and Meischner 1985). On the basis of flat colony morphology, numerous workers (e.g. Rosen et al. 2002; Martindale et al. 2012; Novak et al. 2013; Kołodziej et al. 2018) have demonstrated the presence of photosymbiosis in Mesozoic and Cenozoic scleractinians. MCEs dominated by platy forms have also been recognized in the Devonian, but these reefs were composed of tabulate and rugose corals, the Palaeozoic ecological predecessors of reef-building scleractinians (Zapalski et al. 2017a; Zatoń et al. 2018; Jakubowicz et al. in press).

The mid-Palaeozoic (Silurian and Devonian) was an interval of significant reef expansion (Copper 1994, 2002; Wood 1999; Flodén et al. 2001). Great barrier reef systems covered a substantially greater percentage of seafloor than the reefs of the Recent (Copper 2002), and large reefs are known to have developed at high latitudes (Kaufmann 2003; Jakubowicz et al. in press). This extensive reef 
development could possibly be the result of the acquisition of photosymbionts - at the latest, by the mid-Silurian, and potentially as early as the late Ordovician (Zapalski 2014). Indeed, a potential Ordovician origin of coral-algae symbiosis would coincide with the Great Ordovician Biodiversification Event (Servais and Harper 2018). These great mid-Palaeozoic reef systems vanished in the Late Devonian (Late Frasnian, ca. $377 \mathrm{Ma}$ ), possibly due to the global rise of temperatures above $32{ }^{\circ} \mathrm{C}$ in tropical surface waters and a consequent bleaching-like event recorded by significant changes in coral colony architecture, followed by a sharp cooling event (Zapalski et al. 2017b). If photosymbiosis was responsible for the intense mid-Palaeozoic development of reefs, and MCEs were found in the Devonian, it is reasonable to suggest that MCEs first appeared shortly after the acquisition of photosymbionts. In this framework, then, the oldest MCEs should therefore be of similar age to the large Silurian reefal structures. (Here, the term "reef" is used in the broadest possible meaning, e.g. Wood 1999.)

During the Silurian, the Baltic Basin-on the palaeocontinent of Laurussia, Baltica subcontinent (currently, NE Europe) - was located at low latitudes (Calner et al. 2004a, Torsvik and Cocks 2013; Fig. 1a), resulting in the extensive development of reefs on its shelfs. These widespread reefs extended from Gotland (Sweden) through Estonia to Podolia (Ukraine) along the Baltica shelf (Euczyński et al. 2009; Tuuling \& Flodén 2013). In particular, Gotland is among the best-documented examples of the middle Silurian reefal environments, with a substantial component formed of tabulate corals mostly developed as prominent bioherms (Manten 1971). Since the geological sequence exposed on its shores (Fig. 1b, c) also records deeper facies below the main reefal complexes, Gotland represents an ideal locality to test the existence of Silurian MCEs.

\section{Materials and methods}

\section{Geological setting}

The Silurian strata exposed on Gotland range from the latest Telychian to the Ludfordian (Calner et al. 2004a); widespread bioherms are known (Manten 1971). The oldest beds exposed on the island are the Lower Visby Beds (Lower Wenlock, Sheinwoodian, Lower Ps. bicornis to Lower $P$. procerus Zones; Fig. 2), consisting of alternating limestone-marl beds with scattered halysitid biostromes (Stel 1978; Nield 1982; Berkowski and Zapalski 2018) and solitary button-shaped rugose corals Palaeocyclus porpita in the uppermost parts of the Lower Visby Beds. This taxon is indicative of the Lower Visby Beds and ranges to the top of this unit (Calner et al. 2004a). The Lower Visby Beds were deposited in relatively deep environments, most likely below the photic zone (Samtleben et al. 1996; Calner et al. 2004a), with abundant bioturbations under well-oxygenated conditions (Samtleben et al. 1996). The border between the Lower and Upper Visby Beds is marked by the presence of the large rugose coral Phaulactis, an excellent ecostratigraphic marker that allows for robust correlations between sections (Samtleben et al. 1996). Overlying Upper Visby Beds (Upper $P$. procerus to Lower $K$. ranuliformis Zones) are less regularly bedded, with increased limestone to marl ratios, and detrital beds in the upper part (Calner et al. 2004a). These beds were formed in a somewhat shallower setting (as evidenced by the presence of erosional surfaces, ripple marks and algae), likely within the photic zone (Calner et al. 2004a); fossil algae suggest the deposition depth of this unit was less than $100 \mathrm{~m}$ (Riding 1979). The Upper Visby Beds represent distal shelf environments, with tabulate corals, solitary rugose corals, trilobites, brachiopods and bryozoans. The overlying strata (Högklint Formation) represent shallow-water environments and contain numerous coral-stromatoporoid reefs (Manten 1971; Calner et al. 2004a).

The uppermost strata of the Lower Visby Beds (ca. 2-3 $\mathrm{m}$ below the Phaulactis layer) were studied in two sections (Fig. 1c). The first is located on the shore between Ygne and Högklint (Fig. 3a) south of Visby (between approximately $57^{\circ} 35^{\prime} 37.15^{\prime \prime} \mathrm{N}, \quad 18^{\circ} 11^{\prime} 28.26^{\prime \prime} \mathrm{E}$ and $57^{\circ} 35^{\prime} 48.19^{\prime \prime} \mathrm{N}, 18^{\circ} 11^{\prime} 45.19^{\prime \prime} \mathrm{E}$; the southern point corresponds to the Rövar Liljas Håla locality of Calner et al. (2004b)). The second is Ireviken (Fig. 3b), located on the shore near $57^{\circ} 50^{\prime} 40.632^{\prime \prime} \mathrm{N}, 18^{\circ} 34^{\prime} 1.379^{\prime \prime} \mathrm{E}$; this site corresponds to the Ireviken 2 locality of Calner et al. (2004b; see also Berkowski and Zapalski 2018). In each of these sites, the beds with platy corals are exposed on distance up to $500 \mathrm{~m}$ along the coast. The distance between the two sites is approx. $41 \mathrm{~km}$, and this distance faithfully reflects the palaeodistance in the Silurian. The taxonomy of tabulate corals from the Gotland Silurian was first studied by Stasińska (1967); the most current list of tabulate taxa from the Visby Beds is that of Mõtus (2005).

\section{Material}

Since the Gotland shoreline is protected under the Nature 2000 legislation and the use of hammers in these sites is strictly prohibited, we collected weathered specimens from the cliff scree and only made observations in the exposed beds. Approximately 100 tabulate specimens were collected from both sites. These were cleaned with a brush and then soaked in $30 \%$ hydrogen peroxide to remove clay particles. Thin sections of selected colonies (38) were prepared. The specimens illustrated in this study were 

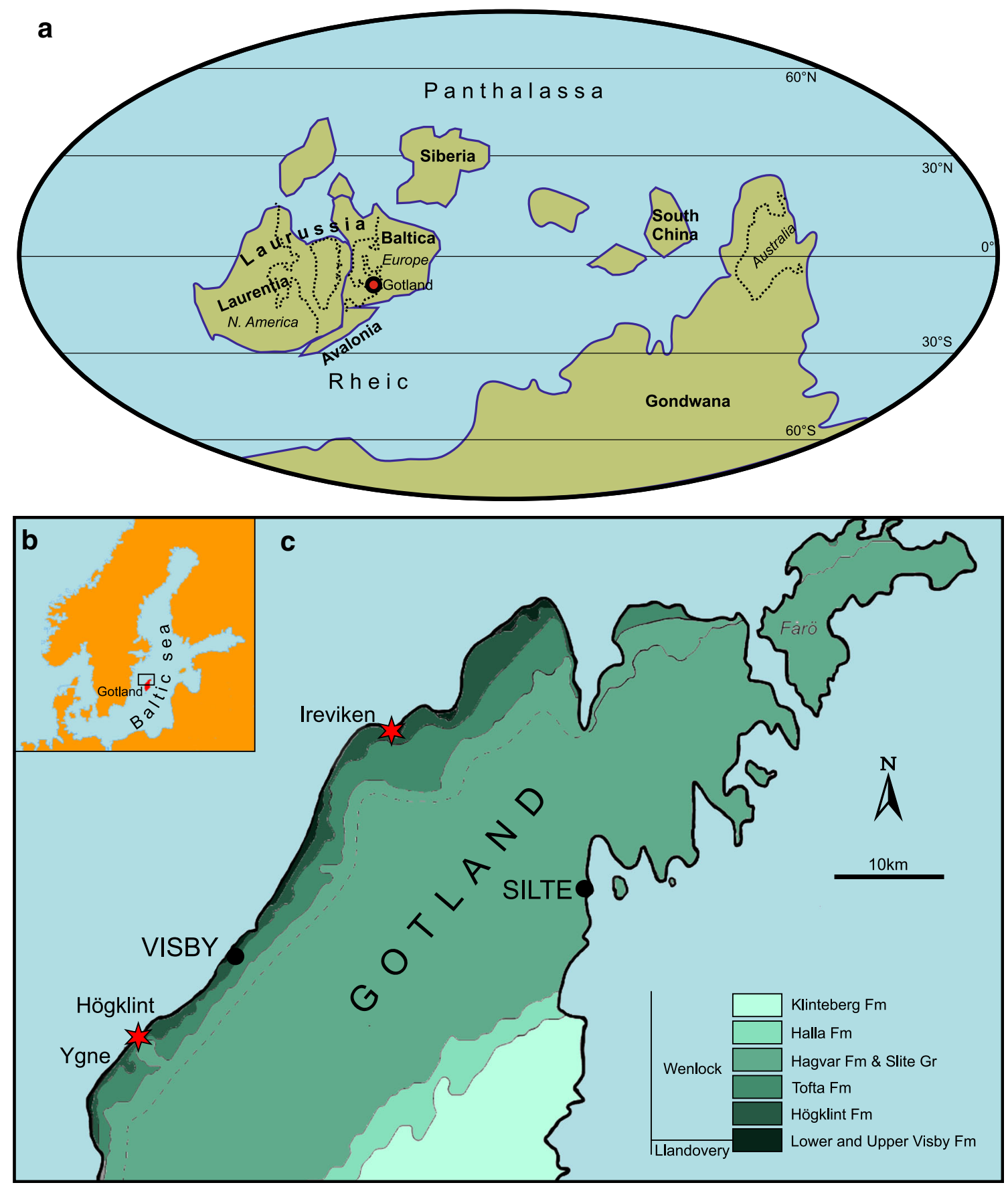

Fig. 1 a Palaeogeographical map showing continents in the midSilurian (430 Ma), with the location of study sites. Note that the map shows the borders of continental plates, not the coastline. Paleocontinents signed in bold, modern continents in italics, paleooceans in normal font. Laurussia is the new continent formed after collision of

coated with ammonium chloride and photographed with a Canon EOS 70D camera with a 100-mm macro lens. This collection is housed at the Museum of the Faculty of Geology, University of Warsaw.
Baltica, Avalonia and Laurentia. Modified after Torsvik and Cocks (2013). b Location of study area on the map of Europe. c A sketch of geological map of northern Gotland. Asterisks show investigated localities. Based upon Calner et al. (2004a)

\section{Results}

As the depositional setting is very similar in both sites, we present below an integrated description. If a phenomenon only occurs at one site, we explicitly denote it. 


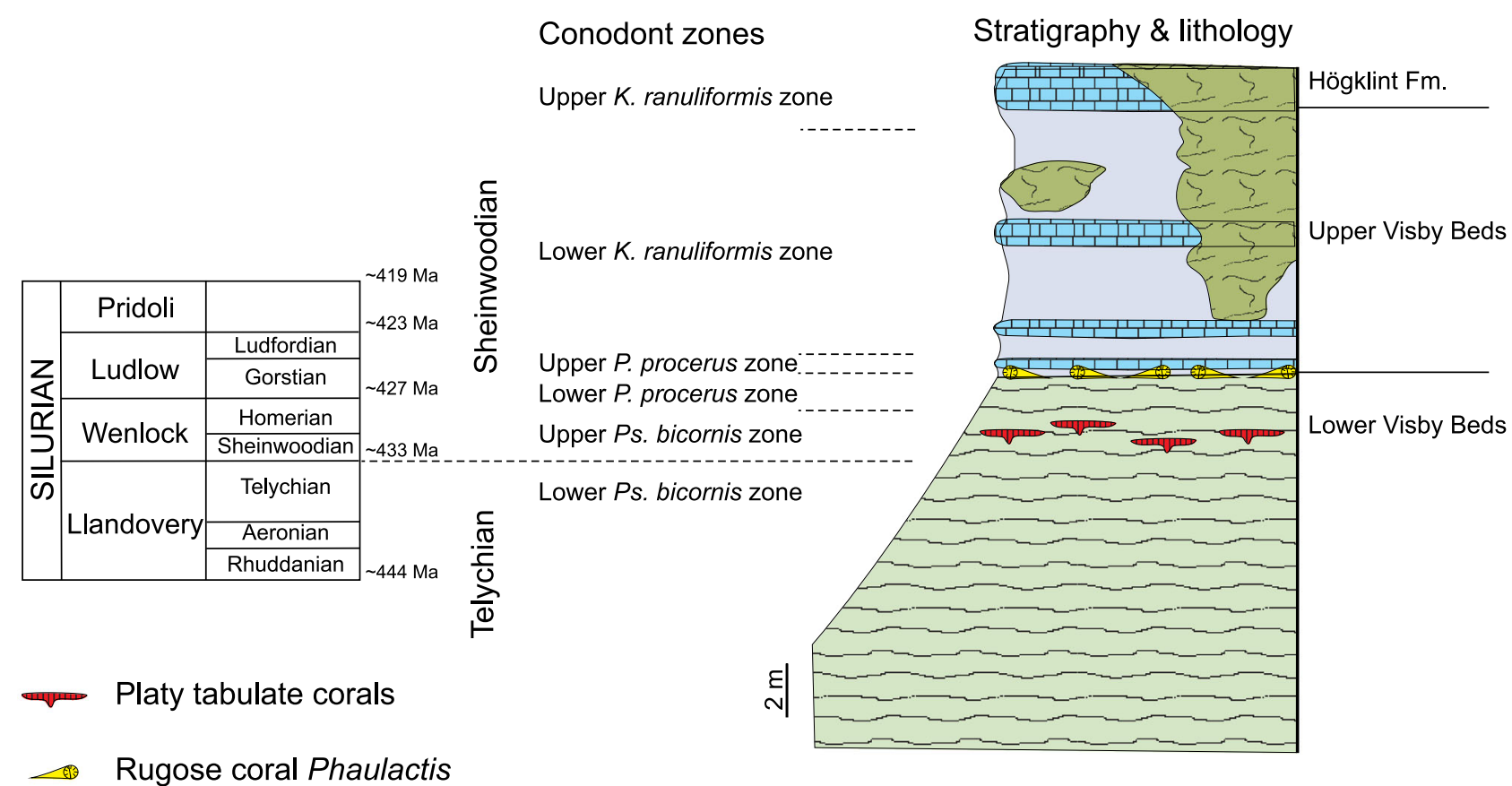

Reef mound

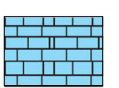

Bioclastic limestone

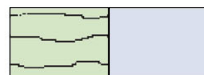

Regular/irregular limestone-marl alteration

Fig. 2 Stratigraphy of the investigated section, based upon figure by Calner et al. (2004a)


Fig. 3 a The cliffs between Ygne and Högklint. b The cliff at Ireviken. The dotted lines show approximate bottom of observed beds with platy coral communities

The tabulate corals in the Upper Visby Beds are scattered in the sediment; in general, they do not form a skeletal framework. The upper parts of Lower Visby Beds contain halysitid biostromes, in which these tabulates form large, cateniform colonies. In the uppermost 2-3 $\mathrm{m}$ of the Upper Visby Beds, halysitids become very rare to absent and are replaced by heliolitids, favositids and alveolitids that form platy colonies (Fig. 4a, b). Our field estimations in both localities show that at least $70-80 \%$ of tabulate colonies (with the exception of halysitids) observed in situ in the uppermost Lower Visby Beds and lowermost Upper Visby Beds have width-to-height ratios ranging from 4:1 to $\sim 15: 1$, with the largest colonies exceeding $30 \mathrm{~cm}$ in diameter. Their upper surfaces are either uniformly flat (with thickenings in places of intensive growth) or have platy rejuvenations, but in general the total colony thickness rarely exceeds $2-3 \mathrm{~cm}$. All of the tabulate corals in the uppermost Lower Visby Beds are in growth positions, and we did not encounter any overturned or inclined colonies. In both sites, the tabulate colonies form sometimes-small associations ("micro patch reefs"), which generally ranged $50 \mathrm{~cm}$ to $1 \mathrm{~m}$ in diameter. Solitary rugose corals, encrusting bryozoans, crinoid columnals and sporadic brachiopods are found in association, along with reported 
Fig. 4 Examples of platy tabulate corals in situ in Högklint and Ireviken. a, b Dashed lines show the platy colonies in situ, Högklint. c Micro patch reef, with massive halysitid coral (Ha) at the bottom, with incorporated solitary rugose corals, all in situ ( $\mathrm{R}$, probably a cystiphyllid; for details see Berkowski and Zapalski 2018), overgrown by platy, possibly photosymbiotic heliolitid, Ireviken. d Top view of heliolitid tabulate, with corallites and colony structure visible. a, b Coin diameter is $18.5 \mathrm{~mm}$; $\mathbf{c}, \mathbf{d}$ coin diameter is $23.0 \mathrm{~mm}$
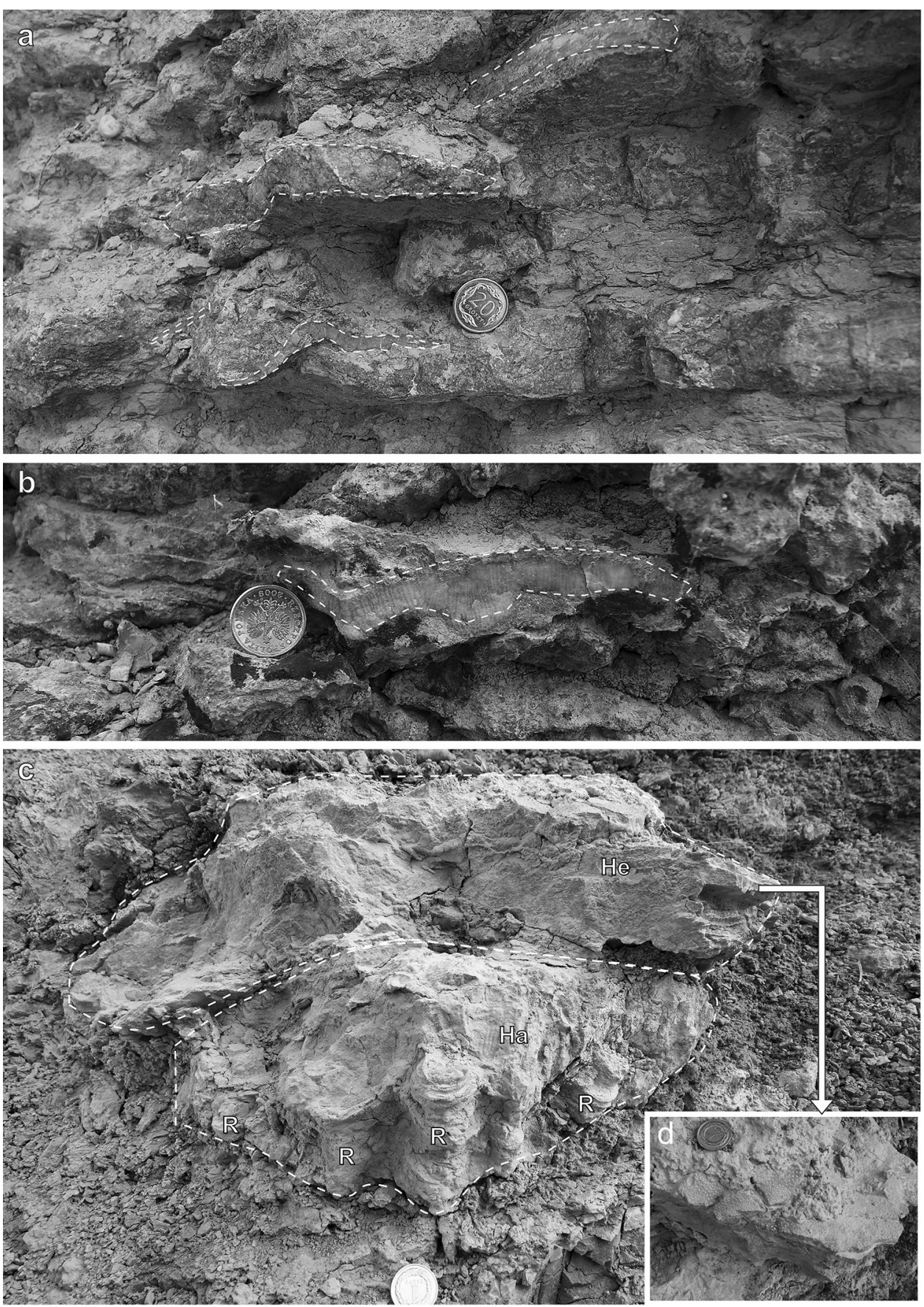

octocoral spicules (one species, Bengtson 1981); stromatoporoids (calcareous sponges) are notably absent. In Ireviken, a large colony of Halysites with incorporated solitary rugose corals formed a base of a "micro patch reef", overgrown by platy halysitids (Fig. 4c, d). The entire patch is about $25 \mathrm{~cm}$ high and about $40 \mathrm{~cm}$ wide. The tabulate colonies collected from debris in the nearest vicinity of this patch have width-to-height ratios of approximately 6-10:1 (Figs. 5, 6). Some platy tabulate specimens are encrusted by epibionts on both their upper and lower surfaces: bryozoans and brachiopods generally constitute the most abundant epibionts (Figs. 5, b, d, g, i, $6 \mathrm{~b}, \mathrm{c})$. Platy colonies in both Ireviken and Ygne-Högklint are most commonly formed by representatives of the genera Heliolites, Plasmopora, Favosites, Mesofavosites, Subalveolites and Planalveolites. We have also found some rare branching forms representing the genera Cladopora and (?) Alveolitella.

The rugose corals of the Lower Visby Beds are mostly represented by relatively large solitary dissepimented 

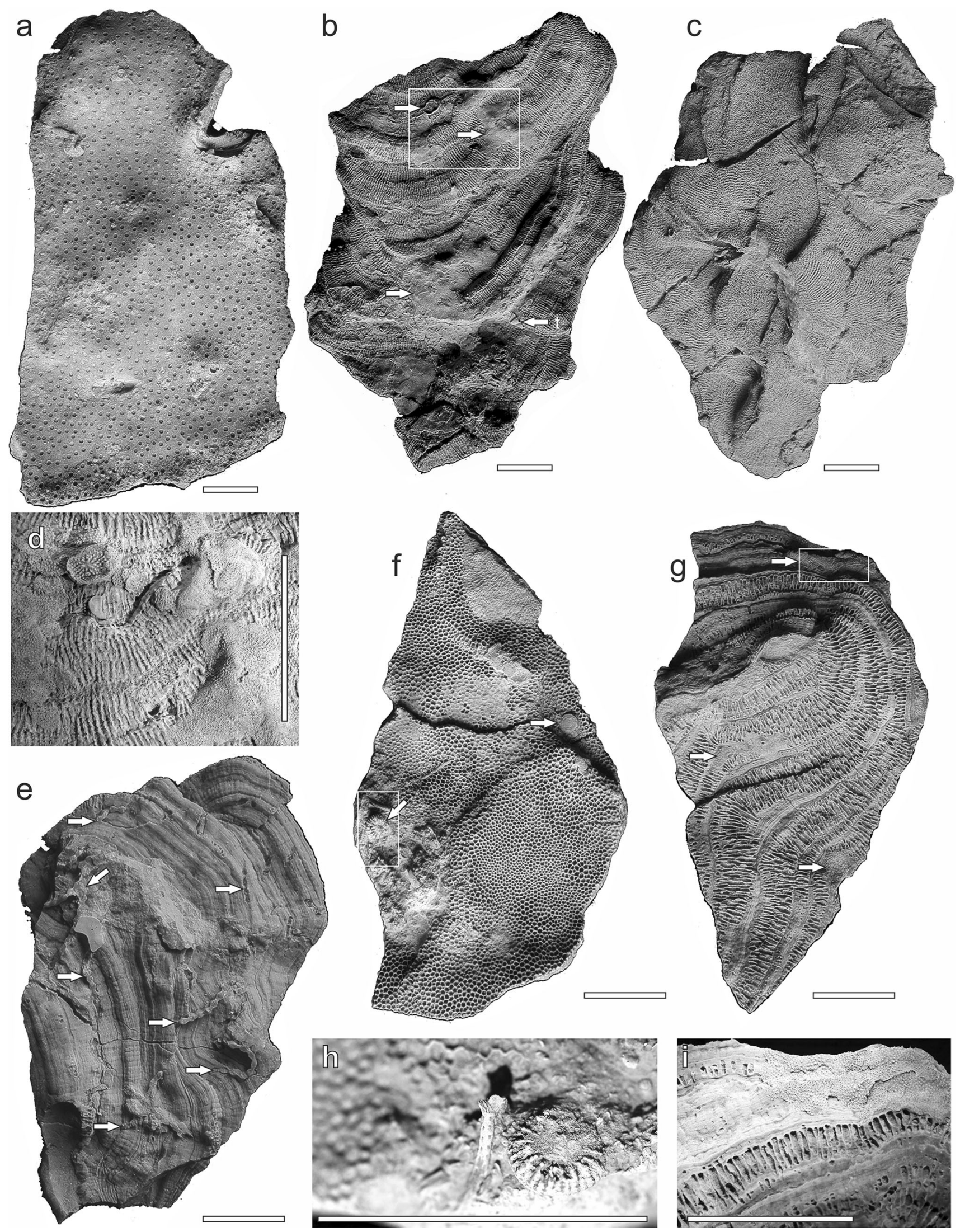
४Fig. 5 Examples of platy corals from Ireviken. a Heliolitid, top surface, colony thickness is $1-2 \mathrm{~cm}$. b Alveolitid, bottom surface encrusted by bryozoans (arrows) and attached (post-mortem) trilobite pygidium ( $\mathrm{t}$ ). Box indicates magnification on $\mathbf{d}$. The colony is $0.5-2.0 \mathrm{~cm}$ thick. c Same specimen, top surface. d Same specimen, bottom surface, magnification on encrusting bryozoans from the box on b. e Favositid, bottom surface showing remains of a halysitid (arrows) to which it was attached. This colony grew on top of a "micro patch reef". The thickness of this colony is from 0.5 to $2.0 \mathrm{~cm}$ in rejuvenated parts. f Favositid top surface, with attached (postmortem) Palaeocyclus porpita (arrows, box indicates magnification on h) indicative of the Lower Visby Beds. g Same specimen, bottom surface, arrows show encrusting bryozoans (box indicates magnification on i). The thickness of this colony is from 0.6 to $2.1 \mathrm{~cm}$ (in the place of attachment scar). h same specimen, top surface, Palaeocyclus porpita with a fragment of branching bryozoan, magnification of the box on f. i Same specimen, bottom surface, magnification on encrusting bryozoans from the box on $\mathrm{g}$. Scale bar for all specimens $20 \mathrm{~mm}$

genera of cystiphyllid (Cystiphyllum), and lykophyllid (Phaulactis, see Adomat et al. 2016) corals. Apart from these large taxa, numerous smaller undissepimented streptalasmatids (Dinophyllum and Crassilasma) are present. Button-shape cystiphyllid genus (Palaeocyclus) and peculiar operculate cystiphyllid genera (Goniophyllum and Araeopoma) are sporadically reported within the lower
Visby beds (see, e.g. Johannessen 1993, 1995a). Colonial corals are represented only by minute phaceloid coralla (Nanophyllum see: Johannessen 1995b; Berkowski and Zapalski 2018). These solitary taxa suggest the existence of rhizosessile and liberosessile life strategies sensu Neumann (1988; see also summary of Scrutton 1998), which allowed them to live within soft substrates. Moreover, they often display various types of rejuvenescence during growth, manifested by constrictions and expansions of the corallites, which document the instability of the soft bottom (see, e.g. Berkowski 2012).

\section{Discussion}

\section{Photosymbiosis and the function of platy morphology}

There are two possible functions of platy colony morphologies: stabilization in soft sediment and photoadaptive growth (Insalaco 1996). The Lower Visby Beds consist of strata that originally formed a muddy, unconsolidated seafloor (Munnecke and Samtleben 1996; Munnecke et al. 2003; Calner et al. 2004a), as shown by the adaptations of
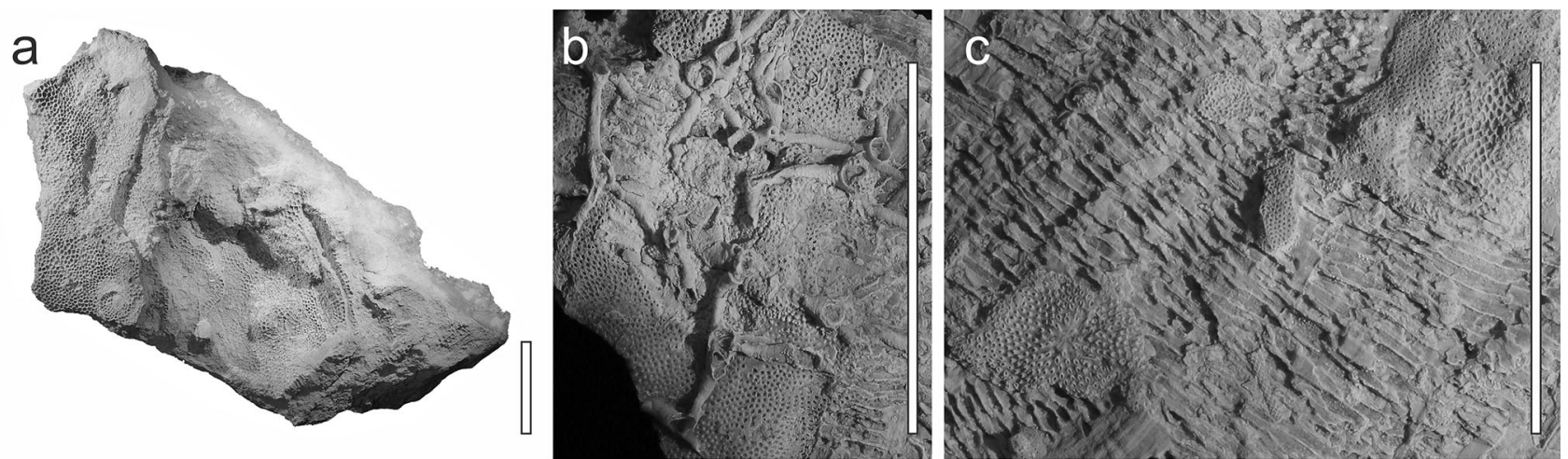
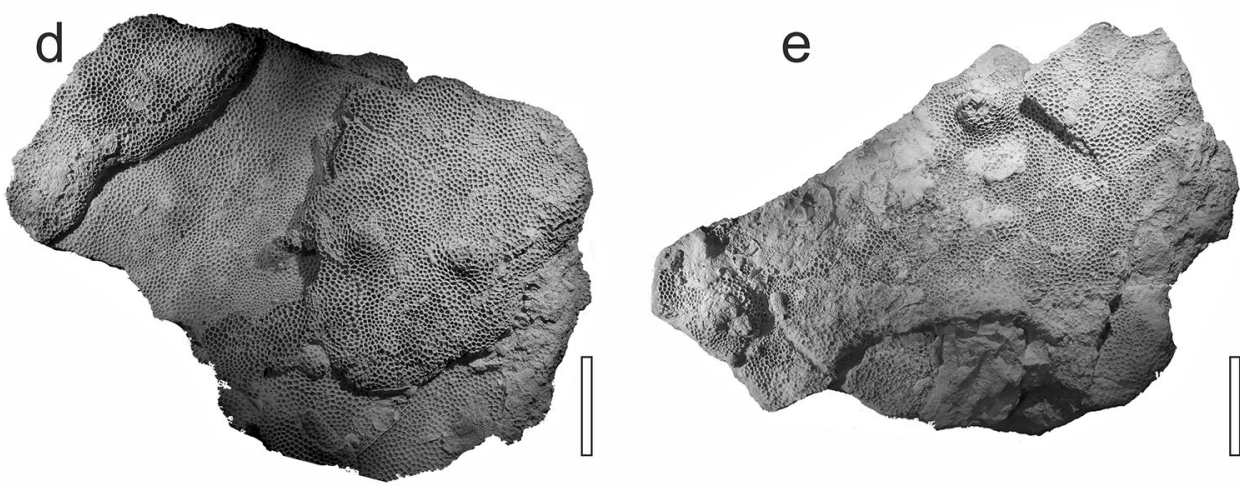

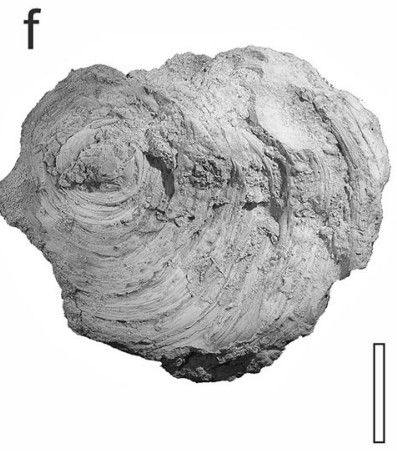

Fig. 6 Examples of platy corals from Högklint. a Favositid, top surface, about $1.8 \mathrm{~cm}$ maximum thick. b Same colony, lower surface, encrusting auloporid coral on bryozoan. c Same colony, bottom surface, encrusting bryozoan. d Nearly complete colony of favositid, top surface, about $1.5 \mathrm{~cm}$ maximum thickness. e Fragment of platy favositid colony, top surface, about $30 \mathrm{~mm}$ thick in the thickest (rejuvenation) place. f Complete heliolitid colony, bottom surface, $0.8-2.5 \mathrm{~cm}$ thick (rejuvenation). Scale bar for all specimens $20 \mathrm{~mm}$ 
solitary rugose corals. If the adaptation to soft substratum had primary control over coral growth, in places with hard substrate these colonies would have possessed non-platy morphologies (i.e. bulbous or branching). In places where heliolitids and favositids grew on halysitids (Figs. 4c, 5e: see also Stel 1978, fig. 14; Nield 1982), such a hard substratum was available, yet the former still formed platy colonies; this suggests that photophilic growth, rather than adaptation to soft substrate, was the driving factor behind platy morphology development. Moreover, numerous platy colonies also display epibionts on their lower surfaces (Figs. 5b, d, g, i, 6b, c), which could be possible in two circumstances: (i) when colonies formed an overhang, thus fostering cryptic communities, or (ii) in the case when colonies were overturned by currents or wave action. The former seems to be more probable, as the Lower Visby Beds are considered to record a deep environment at the lower limit of the euphotic zone (Samtleben et al. 1996; Calner et al. 2004a) — depths at which wave action is nearly non-existent. The sedimentation rates were possibly low, as in the case of high sedimentation rates cryptic encrusters would not be able to survive on these lower surfaces. In their study on Triassic mesophotic ecosystems, Kołodziej et al. (2018) suggested that encrusting epibionts on the undersides of colonies might be used as an argument for slow sedimentation rates. Another argument against high sedimentation rates is that in several cases the corallites at the edge of a platy colony are bent downwards, or-in extreme cases - the edge of the entire colony wrapped with downward-facing inferred polyps. This would not be possible in the case of a flat colony lying on a muddy substrate. Consequently, adaptation to soft substratum as the dominant factor driving platy morphology can be readily excluded.

Platy morphology is generally regarded as providing indirect evidence for photoadaptive growth and is a wellknown adaptation of photosymbiotic corals to environments with depleted light (e.g. Graus and Macintyre 1976, 1982; Rosen et al. 2002; Anthony and HoeghGuldberg 2003; Kahng et al. 2010, 2012, 2014). This type of morphology generally does not occur in azooxanthellates (Fricke and Meischner 1985), and if platy forms occur in azooxanthellates (such as Leptoseris troglodyta), they rarely exceed $1 \mathrm{~cm}$ of maximal colony diameter (Hoeksema 2012); therefore, platy morphology can be treated as a robust indicator for photosymbiosis (e.g. Rosen et al. 2002; Martindale et al. 2012; Zapalski et al. 2017a; Kołodziej et al. 2018). Most tabulate corals from Lower Visby Beds are characterized by moderate to high colony integration and small corallite diameters, both parameters also characteristic of photosymbiotic corals (Coates and Jackson 1987; see discussion by Zapalski et al. 2017a, b), which serves as further support for their photosymbiotic nature. This coincides with the onset of photosymbiosis in tabulate corals during the Sheinwoodian, which was postulated by Zapalski (2014) on the basis of stable isotope signatures (but see the contrary view by Jakubowicz et al. (2015) on the basis of rugose coral analysis). The morphological evidence provided here (platy morphology, small corallites, moderate colony integration), however, advocates for photosymbiotic relationship within tabulate species (see Zapalski et al. 2017a).

The morphology of tabulate corals in the overlying Upper Visby Beds and Högklint Formation is more variable, with more frequent massive and irregular colonies and a visible decrease in the abundance of platy morphologies. As the overlying beds represent a shallowing trend, it seems that the Silurian distribution of coral morphologies along depth gradients is similar to that known from the Devonian (Zapalski et al. 2017a), and from the Recent: massive forms generally predominate in shallow waters, while platy forms tend to appear in deeper settings (Hallock and Schlager 1986; Riegl and Piller 1997; Hallock 2005).

\section{MCEs in the Palaeozoic}

Palaeozoic MCEs dominated by photosymbiotic tabulate corals were described from the Middle Devonian of the Holy Cross Mountains, Poland (Zapalski et al. 2017a, Zaton et al. 2018) and noted in the Middle Devonian of Anti-Atlas, Morocco (Jakubowicz et al. in press). The MCEs documented herein from Gotland are about $40 \mathrm{Ma}$ older, thus rendering them the oldest MCEs observed to date. The similarities between the Silurian and Devonian MCEs include the dominance of platy corals (but with somewhat different taxonomic composition, mostly on a generic level with the notable absence of platy heliolitids in the Devonian) and the relatively common appearance of brachiopod and crinoid fauna; their differences include the lack of frondescent forms in the Silurian which are common in Devonian MCEs (such as representatives of the genus Platyaxum) and a smaller contribution from branching tabulates in the Gotland localities.

Algae are quite common in recent MCEs. While algal fossils appear sporadically in the Upper Visby Beds, in the case of the Lower Visby Beds they are probably absent (Riding 1979). This may be a taphonomic bias, as aragonitic fossils are usually not preserved in these marly beds (Munnecke et al. 1999); furthermore, algae, if present, may have been primarily non-mineralized. It is worth noting that Devonian MCEs (Zapalski et al. 2017a) were also devoid of algae. If this absence is primary, this would render Palaeozoic MCEs different from these known from modern seas, but it must be emphasized that this may be a result of taphonomic bias. 
The platy corals at both Ireviken and Ygne-Högklint do not form skeletal frameworks; the typical reef skeletal framework is visible only in places where large halysitid colonies are overgrown. In most places, colonies are scattered, and within a single bed spaced apart in an irregular manner (see Stel 1978: his fig. 8). This sort of coral dispersion is characteristic for MCEs in the recent seas, where the living coral cover is greatly variable: in the Bahamas, the coral cover in the mesophotic zone can vary from 3 to 23\% (Liddell et al. 1997), and in the Enewetak Atoll (Marshall Island), as little as $1 \%$ at $90 \mathrm{~m}$ depth (Colin et al. 1986). In general, the coral cover in mesophotic environments is low (e.g. Lesser et al. 2009; Kahng et al. 2010), which constitutes a clear parallelism between our Silurian and Recent MCEs.

Recent MCEs may cover considerable surfaces of the seafloor (Bare et al. 2010). The distance between the discussed two sites is about $41 \mathrm{~km}$, which is faithful to the presumed Silurian palaeodistance. Assuming that the Lover Visby beds are laterally continuous and they contain platy corals throughout their whole extent, we estimate that this MCE was at least $40 \mathrm{~km}$ long. Such a large extent of mesophotic ecosystems is similar to the expanse of modern MCEs, such as these of Samoa (Bare et al. 2010) or Hawaii (Rooney et al. 2010).

We have shown that the platy coral assemblages of the uppermost Lower Visby Beds were MCEs. It seems that such environments were more common in the tropical seas of the Silurian. In the extensive Silurian reefs of Anticosti Island in Canada (Laurentian section of Laurussia shelf), large parts of the reef were dominated by platy tabulate corals. The pioneering communities of these reefs were composed of halysitids, later overgrown by platy and laminar tabulates and stromatoporoid sponges (Brunton and Copper 1994). This situation is very similar to that observed in the Lower Visby Beds. In Anticosti, tabulates such as Alveolites, Favosites and "Coenites" (it is likely that these are probably Platyaxum or Roseoporella) formed colonies 2-5 cm high and 20-80 cm in diameter (Brunton and Copper 1994). Although their environments were interpreted as shallow (Brunton and Copper 1994) it may be possible that this candidate MCE developed in shallower environments, due to elevated turbidity levels.

Another possible MCE is the early Silurian (Rhuddanian) Hilliste Fm. on the Estonian island of Hiiumaa, which records shallowing-upward environments between stormand normal wave-base (Matt et al. unpublished). Argillaceous beds at the base of the formation contain corals, brachiopods and stromatoporoids. During fieldwork in the Hilliste quarry (August 2014), we noticed numerous platy coralla of favositids in the lowermost exposed beds of the formation. It has been demonstrated that the base of this formation likely represents environments between storm- and normal wave-base (Matt et al. unpublished), fitting in well with the characteristics of a possible mesophotic environment. Consequently, we can infer that these rocks may also record a MCE, but this site requires further study.

The earliest MCEs (Sheinwoodian of Gotland, $\sim 430 \mathrm{Ma}$, possibly also Rhuddanian, $\sim 440 \mathrm{Ma}$, of Hiiumaa) are largely synchronous with the onset of the development of the great middle Palaeozoic reefs. From the Early Silurian onwards, photosymbiotic tabulates contributed significantly to MCEs, which indicates the onset of photosymbiosis in these taxa. This is sharp contrast to rugose corals, which are mostly represented by solitary and/or phaceloid taxa in these environments and therefore seem to be aposymbiotic. Overall, it seems that the development of Early Palaeozoic tabulate corals is quite similar to that of scleractinians in the Triassic. The acquisition of algal photosymbionts allowed photosymbiotic corals to colonize the seafloor in lower parts of the euphotic zone as early as the Silurian, suggesting that the growth of the prominent Siluro-Devonian reefs was likely driven by the onset of photosymbiosis.

Acknowledgements We are very grateful to Prof. Ian D. Somerville (Dublin) and an anonymous referee for valuable comments. Wojciech Kozłowski (Warsaw) is thanked for discussions on Silurian palaeogeography. Separate thanks are due to Jordan Todes (Chicago) for linguistic check of this paper. This research was funded by the National Science Center of Poland (Decision No. DEC-2013/09/D/ ST10/04058)

\section{Compliance with ethical standards}

Conflict of interest On behalf of all authors, the corresponding author states that there is no conflict of interest.

Open Access This article is distributed under the terms of the Creative Commons Attribution 4.0 International License (http://crea tivecommons.org/licenses/by/4.0/), which permits unrestricted use, distribution, and reproduction in any medium, provided you give appropriate credit to the original author(s) and the source, provide a link to the Creative Commons license, and indicate if changes were made.

\section{References}

Adomat F, Munnecke A, Kido E (2016) Mass occurrence of the large solitary rugose coral Phaulactis angusta at the boundary Lower/ Upper Visby Formation in the Silurian of Gotland, Sweden: Palaeoecology and depositional implications. GFF 138:393-409

Anthony KRN, Hoegh-Guldberg O (2003) Variation in coral photosynthesis, respiration and growth characteristics in contrasting light microhabitats: an analogue to plants in forest gaps and understoreys? Funct Ecol 17:246-259

Baker E, Puglise KA, Colin PL, Harris PT, Kahng SE, Rooney JJ, Sherman C, Slattery M, Spalding HL (2016) What are mesophotic coral ecosystems? In: Baker EK, Puglise KA, Harris PT (eds) Mesophotic coral ecosystems-a lifeboat for coral 
reefs?. The United Nations Environment Programme and GRIDArendal, Nairobi and Arendal

Bare AY, Grimshaw KL, Rooney JJ, Sabater MG, Fenner D, Carroll B (2010) Mesophotic communities of the insular shelf at Tutuila, American Samoa. Coral Reefs 29:369-377

Bengtson S (1981) Atractosella, a Silurian alcyonacean octocoral. Journal of Paleontology 55:281-294

Berkowski B (2012) Life strategies and function of dissepiments in rugose coral Catactotoechus instabilis from the Lower Devonian of Morocco. Acta Palaeontol Pol 57:391-400

Berkowski B, Zapalski MK (2018) Large dwellers of the Silurian Halysites biostrome: rhizosessile life strategies of cystiphyllid rugose corals from the Llandovery of Gotland. Lethaia. 51(4):581-595

Brunton FR, Copper P (1994) Paleoecologic, temporal, and spatial analysis of early Silurian reefs of the Chicotte Formation, Anticosti Island, Quebec, Canada. Facies 31:57-79

Calner M, Jeppsson L, Munnecke A (2004a) The Silurian of Gotland-Part I: Review of the stratigraphic framework, event stratigraphy, and stable carbon and oxygen isotope development. Erlanger geologische Abhandlungen, Sonderband 5:113-131

Calner M, Jeppsson L, Munnecke A (2004b) The Silurian of Gotland-Part II: guide to the IGCP 503 field meeting 2004. Erlanger geologische Abhandlungen, Sonderband 5:133-151

Coates AG, Jackson JBC (1987) Clonal growth, algal symbiosis, and reef formation by corals. Paleobiology 13:363-378

Colin PL, Devaney DM, Hillis-Colinvaux L, Suchanek TH, Harrison JT (1986) Geology and biological zonation of the reef slope, 50-360 m depth at Enewetak Atoll, Marshall Islands. Bull Mar Sci 38:111-128

Copper P (1994) Ancient reef ecosystem expansion and collapse. Coral Reefs 13:3-11

Copper P (2002) Silurian and Devonian reefs: 80 million years of global greenhouse between two ice ages. SEPM Special Publication 72:181-238

Flodén T, Bjerkéus M, Tuuling I, Eriksson M (2001) A Silurian reefal succession in the Gotland area, Baltic Sea. GFF 123:137-152

Fricke H, Meischner D (1985) Depth limits of Bermudan scleractinian corals: a submersible survey. Mar Biol 88:175-187

Graus RR, Macintyre IG (1976) Light control of growth form in colonial reef corals: computer simulation. Science 193(4256):895-897

Graus RR, Macintyre IG (1982) Variation in growth forms of the reef coral Montastrea annularis (Ellis and Solander): a quantitative evaluation of growth response to light distribution using computer simulation. Smithson Contrib Mar Sci 12:441-464

Hallock P (2005) Global change and modern coral reefs: new opportunities to understand shallow-water carbonate depositional processes. Sediment Geol 175:19-33

Hallock P, Schlager W (1986) Nutrient excess and the demise of coral reefs and carbonate platforms. Palaios 1:389-398

Hoeksema BW (2012) Forever in the dark: the cave-dwelling azooxanthellate reef coral Leptoseris troglodyta sp. n. (Scleractinia, Agariciidae). ZooKeys 228:21-37

Insalaco E (1996) Upper Jurassic microsolenid biostromes of northern and central Europe: facies and depositional environment. Palaeogeogr Palaeoclimatol Palaeoecol 121:169-194

Jakubowicz M, Berkowski B, Correa ML, Jarochowska E, Joachimski M, Belka Z (2015) Stable isotope signatures of middle Palaeozoic ahermatypic rugose corals-deciphering secondary alteration, vital fractionation effects, and palaeoecological implications. PLOS ONE 10:e0136289. https://doi.org/10.1371/ journal.pone.0136289

Jakubowicz M, Król J, Zapalski MK, Wrzołek T, Wolniewicz P, Berkowski B (in press) At the southern limits of the Devonian reef zone: Palaeoecology of the Aferdou el Mrakib reef
(Givetian, eastern Anti-Atlas, Morocco). Geological Journal [https://doi.org/10.1002/gj.3152]

Johannessen WH (1993) Species of the Silurian operculate coral genus Goniophyllum. GFF 115:119-143

Johannessen WH (1995a) Species of the Silurian operculate rugose coral genera Araeopoma and Rhytidophyllum. GFF 117:31-41

Johannessen WH (1995b) Nanophyllum, a new monotypic rugose coral genus from the Lower Silurian of Gotland. GFF 117:53-55

Kahng SE, Copus JM, Wagner D (2014) Recent advances in the ecology of mesophotic coral ecosystems (MCEs). Curr Opin Environ Sustain 7:72-81

Kahng SE, Garcia-Sais JR, Spalding HL, Brokovich E, Wagner D, Weil E, Hinderstein L, Toonen RJ (2010) Community ecology of mesophotic coral reef ecosystems. Coral Reefs 29:255-275

Kahng SE, Hochberg EJ, Apprill A, Wagner D, Luck DG, Perez D, Bidigare RR (2012) Efficient light harvesting in deep-water zooxanthellate corals. Mar Ecol Progr Ser 455:65-77

Kaufmann B (2003) Facies, stratigraphy and diagenesis of Middle Devonian reef-and mud-mounds in the Mader (eastern AntiAtlas, Morocco). Acta Geologica Polonica 48:43-106

Kołodziej B, Salamon K, Morycowa E, Szulc J, Łabaj MA (2018) Platy corals from the Middle Triassic of Upper Silesia, Poland: Implications for photosymbiosis in the first scleractinians. Palaeogeogr Palaeoclimatol Palaeoecol 490:533-545

Lesser MP, Slattery M, Leichter JJ (2009) Ecology of mesophotic coral reefs. J Exp Mar Bio Ecol 375:1-8

Liddell WD, Avery WE, Ohlhorst SL (1997) Patterns of benthic community structure, $10-250 \mathrm{~m}$, the Bahamas. Proc 8th Int Coral Reef Symp 1:437-442

Łuczyński P, Skompski S, Kozłowski W (2009) Sedimentary history of Upper Silurian biostromes of Podolia (Ukraine) based on stromatoporoid morphometry. Palaeogeogr Palaeoclimatol Palaeoecol 271:225-239

Manten AA (1971) Silurian reefs of Gotland. Developments in Sedimentology 13. Amsterdam, Elsevier

Martindale RC, Bottjer DJ, Corsetti FA (2012) Platy coral patch reefs from eastern Panthalassa (Nevada, USA): Unique reef construction in the Late Triassic. Palaeogeogr Palaeoclimatol Palaeoecol 313:41-58

Mõtus MA (2005) Silurian (Llandovery-Wenlock) tabulate corals of Baltoscandia: taxonomy, palaeoecology, distribution. Ph.D. thesis. University of Tartu

Munnecke A, Samtleben C (1996) The formation of micritic limestones and the development of limestone-marl alternations in the Silurian of Gotland, Sweden. Facies 34:159-176

Munnecke A, Samtleben C, Servais T, Vachard D (1999) Semobservation of calcareous micro-and nannofossils incertae sedis from the Silurian of Gotland, Sweden: Preliminary results. Geobios 32:307-314

Munnecke A, Samtleben C, Bickert T (2003) The ireviken event in the lower silurian of Gotland, Sweden-relation to similar palaeozoic and proterozoic events. Palaeogeogr Palaeoclimatol Palaeoecol 195:99-124

Neuman BEE (1988) Some aspects of life strategies of Early Palaeozoic rugose corals. Lethaia 21:97-114

Nield EW (1982) The earliest Gotland reefs: two bioherms from the Lower Visby Beds (upper Llandovery). Palaeogeogr Palaeoclimatol Palaeoecol 39:149-164

Novak V, Santodomingo N, Rösler A, Di Martino E, Braga JC, Taylor PD, Johnson KG, Renema W (2013) Environmental reconstruction of a late Burdigalian (Miocene) patch reef in deltaic deposits (East Kalimantan, Indonesia). Palaeogeogr Palaeoclimatol Palaeoecol 374:110-122

Riegl B, Piller WE (1997) Distribution and environmental control of coral assemblages in northern Safaga Bay (Red Sea, Egypt). Facies 36:141-162 
Rooney J, Donham E, Montgomery A, Spalding H, Parrish F, Boland R, Fenner D, Gove J, Vetter O (2010) Mesophotic coral ecosystems in the Hawaiian Archipelago. Coral Reefs 29:361-367

Rosen BR, Aillud GS, Bosellini FR, Clack NJ, Insalaco E, Valldeperas FX, Wilson MEJ (2002) Platy coral assemblages: 200 million years of functional stability in response to the limiting effects of light and turbidity. Proc 9th Int Coral Reef Symp $1: 255-264$

Samtleben C, Munnecke A, Bickert T, Pätzold J (1996) The Silurian of Gotland (Sweden): facies interpretation based on stable isotopes in brachiopod shells. Geol Rundsch 85:278-292

Scrutton CT (1998) The Palaeozoic corals, II: structure, variation and palaeoecology. Proceedings of the Yorkshire Geological Society 52:1-57

Servais T, Harper DAT (2018) The Great Ordovician Biodiversification Event (GOBE): definition, concept and duration. Lethaia $51: 151-164$

Stasińska A (1967) Tabulata from Norway, Sweden, and from the Erratic Boulders of Poland. Palaeontologia Polonica 18:1-112

Stel JH (1978) Environment and quantitative morphology of some Silurian tabulates from Gotland. Scr Geol 47:1-75
Torsvik TH, Cocks LRM (2013) New global palaeogeographical reconstructions for the Early Palaeozoic and their generation. Geological Society, London, Memoirs 38:5-24

Tuuling I, Flodén T (2013) Silurian reefs off Saaremaa and their extension towards Gotland, central Baltic Sea. Geol Mag 150:923-936

Wood R (1999) Reef evolution. Oxford University Press, Oxford

Zapalski MK (2014) Evidence of photosymbiosis in Palaeozoic tabulate corals. Proc R Soc Lond B Biol Sci 281(1775):20132663. https://doi.org/10.1098/rspb.2013.2663

Zapalski MK, Wrzołek T, Skompski S, Berkowski B (2017a) Deep in shadows, deep in time: the oldest mesophotic coral ecosystems from the Devonian of the Holy Cross Mountains (Poland). Coral Reefs 36:847-860

Zapalski MK, Nowicki J, Jakubowicz M, Berkowski B (2017b) Tabulate corals across the Frasnian/Famennian boundary: architectural turnover and its possible relation to ancient photosymbiosis. Palaeogeogr Palaeoclimatol Palaeoecol 487:416-429

Zatoń M, Zapalski MK, Berkowski B, Wrzołek T (2018) Cryptic encrusting communities in a Middle Devonian mesophotic paleoenvironment of the Holy Cross Mountains, Poland. Palaeogeogr Palaeoclimatol Palaeoecol 501:82-91 